\title{
Soybean proteinase inhibitor and the foraging strategy of free flying honeybees ${ }^{1}$
}

\author{
François-Xavier DECHAUME-MonCHARMONT ${ }^{\mathrm{a} *}$, Hichem AzZOUZ ${ }^{\mathrm{b}}$, Odile PONS ${ }^{\mathrm{c}}$, \\ Minh-Hà PHAM-DELÈGUE ${ }^{d}$ \\ ${ }^{a}$ Centre for Behavioural Biology, University of Bristol, Woodland Road, Bristol BS8 1UG, UK \\ $\mathrm{b}$ Laboratoire de Biologie Animale, Biologie des Entomophages, Université de Picardie Jules Verne, \\ Faculté des Sciences, 33 rue Saint Leu, 80039 Amiens Cedex 1, France \\ c Unité de Biométrie, INRA Centre de Recherche de Jouy-en-Josas, 78352 Jouy-en-Josas Cedex, France \\ $\mathrm{d}$ CNRS, Relations Internationales, 3 rue Michel Ange, 75794 Paris 16, France
}

Received 3 August 2004 - revised 5 December 2005 - accepted 5 January 2005

Published online 7 July 2005

\begin{abstract}
Previous laboratory studies reported disruption of the digestive physiology and learning behaviour in individual honeybees treated with Bowman-Birk inhibitor (BBI), a serine proteinase inhibitor expressed in some GM plants. Our objective was to detect behavioural effects of this transgene on honeybees at the colony level, maintained in laboratory conditions. We set up a choice experiment, based on 150 free-flying individuals which performed a over 7700 visits on the flowers. The mean number of visits per hour, the mean time spent on the feeder and the interval between consecutive visits were not significantly different when the feeding sucrose solution was mixed with BBI at $100 \mu \mathrm{g} \cdot \mathrm{mL}^{-1}$, a dose close to the expression level in planta. The methodology proposed herein could form a colony scale procedure particularly relevant to the risk assessment of the impact on bees of proteinase inhibitors or other transgenes to be possibly expressed in melliferous plants.
\end{abstract}

Apis mellifera / foraging behaviour / behavioural choice / proteinase inhibitor / risk-assessment / Cox model

\section{INTRODUCTION}

Engineering genes that encode insecticidal proteins into crop plants offers numerous benefits to agriculture. However, as with many conventional insecticides, the environmental consequences of this new technology need to be assessed. Most of the environmental concerns about genetic modification (GM) technology in plants are derived from the possibility of gene flow to close relatives of the transgenic plant, the possible undesirable effects of the exotic genes or traits (e.g., resistance in pest insect or herbicide tolerance), and the possible effect on non-target organisms. It is not possible to test all the potential non-target organisms

\footnotetext{
* Corresponding author: fx.dechaume@bristol.ac.uk
}

${ }^{1}$ Manuscript editor: Jean-Noël Tasei in contact with a transgenic crop. Commonly used non-target herbivorous insects are those selected for conservation needs, soil functions and roles in pollination (review by Cowgill and Atkinson, 2003). In particular, it is important to study the impact of insect resistant GM plants on both survival and foraging activity of pollinators. Beneficial insects such as honeybees or bumblebees may be repeatedly exposed to entomotoxins present in the nectar of GM plants. Due to its economical importance, the honeybee Apis mellifera L. is one of the most studied pollinators. The economic value of honey bees results from the hive products (honey, royal jelly, wax, etc.) and from their pollinating activity on crop plants (Williams, 1994). 
A scheme similar to the one used to assess the effect of pesticides on beneficial organisms (EPPO, 1993) has been proposed to assess the effect of insect resistant GM plants on beneficial insects (Dohmen, 1998; Schuler et al., 2001, 2003; Cowgill and Atkinson, 2003). Thus, risk assessment for the honeybee should follow a sequential scheme from laboratory to field evaluations. First, the studies should rely on small-scale laboratory experiments in which individual bees are exposed to high doses of transgene product to assess the lethal effect of the toxin. Second, more extended laboratory or semi-field, hive scale, experiments should be carried out. The ecological and behavioural factors affecting the probability of exposure to toxins should be studied under more controlled conditions than in the field. Third, large scale field studies represent the most realistic scenario.

Among the transgene products capable of protecting a crop against herbivorous insects, the development of transgenic plants expressing proteinase inhibitors (PI) has emerged in the recent years as an additional strategy for pest control (Hilder et al., 1987; Christeller et al., 2002). The proteinase inhibitors slow down the growth or kill the insect by binding with digestive proteinases resulting in the disruption of protein digestion and lack of several amino acids (Hines et al., 1990; Oppert et al., 1993). There are several classes of PIs, and their efficiency depends on the proteinase present in the target-insect. Because previous studies have shown the presence of digestive serine proteinase in the honeybee digestive tract (Moritz and Crailsheim, 1987; Belzunces et al., 1994; Burgess et al., 1996), it can be hypothesized that honeybees foraging on plants expressing serine proteinase inhibitors could be exposed to this transgene product and potentially disturbed or killed. The effect of ingestion of soybean serine proteinase inhibitor (Bowman-Birk inhibitor, BBI) was investigated in small-scale laboratory studies by Girard et al. (1998) and Pham-Delègue et al. (2000). At doses corresponding to the level of expression in planta (Jouanin et al., 1998), this proteinase did not affect honeybee survival (Girard et al., 1998; Pham-Delègue et al., 2000), and long term ingestion did not modify digestive activity (Girard et al., 1998). Individual olfactory learn- ing performances were unchanged (PhamDelègue et al., 2000).

The purpose of this paper was to assess the impact of the soybean proteinase BBI inhibitor on honeybee foraging strategies at the colony level. Our procedure relied on behavioural choice experiments using free flying bees, which could forage either on a contaminated food source or on a control source. We focused on the key components of the foraging strategy: number of visits on each flower, time spent on each flower, and the interval duration between consecutive visits to the flowers.

\section{MATERIALS AND METHODS}

Each experiment was conducted using a queenright colony of about 4000 workers, taken from a tenframe hive and housed in a three-frame hive with little stored nectar. This hive was placed in an indoor flight cage $(2.5 \times 2.2 \times 2.2 \mathrm{~m})$ under controlled conditions $\left(23 \pm 2{ }^{\circ} \mathrm{C}, 55 \pm 10 \% \mathrm{RH}, 12 / 12 \mathrm{~h}\right.$ photoperiod). The colony was allowed one week to settle. Outside the experiment periods, pollen and water were supplied ad libitum.

\subsection{The artificial flowers}

During the experimental periods, individual foragers could collect sucrose solution on two artificial flowers. Each artificial flower was made of three glass dishes (diameter $6 \mathrm{~cm}$ ) delivering sucrose solution ad libitum, and arranged on a $50 \mathrm{~cm}$ turntable with slow rotation (one revolution every three minutes). The three nectar dishes were filled with glass marbles to prevent the honeybee from drowing in the solution. The size of the dishes allowed more than thirty bees to forage on a single flower at the same time, and the rotational movement ensured a homogeneous distribution of the forager bees. As the odour-food association facilitates the location and the learning of the nectar source (von Frisch, 1967; Kriston, 1973; Wenner et al., 1991), we used scent marks of linalool, a floral compound (Blight et al., 1997) well learned by the honeybee (Sandoz et al., 2000). We deposited $10 \mu \mathrm{L}$ of linalool on two strips of filter paper beneath each glass dish. The scent was renewed daily, just before the experiment. Two artificial flowers were arranged symmetrically $1.5 \mathrm{~m}$ apart, $2 \mathrm{~m}$ from the nest entrance, and at a height of $40 \mathrm{~cm}$. The symmetry of the 200 lux illumination on the two flowers was regularly checked. The experimenter sat between the two sources so as not to disturb the foraging activity. 


\subsection{Procedure}

We assessed the impact of the feeding solution quality in experiments lasting 10 days. For each experiment, during the control phase (the first five days), the two artificial flowers delivered identical control feeding solutions. Thus we could check the relative foraging activity on both flowers. During the test phase (the last five days), one flower delivered the test feeding solution while the other still delivered the control solution. We could thus compare the foraging behaviour of the worker bees between flowers, and between the control and the test phases. Each day, at $1300 \mathrm{~h}$, the two artificial flowers were introduced in the flight cage. They were available during a two hour-period, at the end of which they were removed. A forager bee visiting one of the two artificial flowers for the first time was labelled with an individual tag glued on the thorax. The bee was then released on the flower. Her following visits were recorded. The combination of numbers and colours on the tag ensured the unambiguous identification of up to 500 bees. This marking it possible to continuously record the individual foraging activity: the identity of the worker bees, the time of the visit and the flower chosen. For each worker bee we could then determine the mean interval duration between two successive visits. The start of the interval began with a visit on a flower (including the first visit during which the bee was labelled) and it ended when the bee returned to one of the two flowers. Finally, we recorded the behaviour of the foraging bee on the flowers (video camera JVC GR-S707). The experimenter recorded into the camera the numbers of each bee present on the feeder. We then randomly chose bees that could be tracked from their arrival on the flower to their flight back to the hive. For each of these bees, we recorded the duration of their presence on the feeder. Walks on the flower were not included in dance duration. These durations were analyzed in a blind manner using The Observer software (Noldus Information Technology, Wageningen, The Netherlands).

\subsection{Chemical}

The proteinase inhibitor used was BBI soybean Bowman-Birk Inhibitor (Sigma, St-Quentin Fallavier, France). BBI is a serine proteinase inhibitor from soybean displaying high homology with CII (Odani and Ikeneka, 1977) and available in large amounts. The dose chosen $\left(100 \mu \mathrm{g} \cdot \mathrm{mL}^{-1}\right)$ corresponds to the level of expression in planta (Girard et al., 1998; Jouanin et al., 1998) when the transgene expression is controlled by the CaMV-35S promotor, usually $10-100 \mu \mathrm{g}$ per $\mathrm{g}$ fresh weight (Hilder et al., 1987; Johnson et al., 1989; Masoud et al., 1993).

\subsection{Experimental series}

Two experiments lasting 10 days were conducted. A different colony was used in each experiment. For each experiment, the forager's behaviour was recorded during two phases, a control phase then a test phase. In the first experiment, the control sucrose experiment, we modified the sucrose concentration. In the control phase the two flowers delivered a $33 \%(\mathrm{w} / \mathrm{w})$ sucrose solution. For the test phase, the sucrose concentration for the flower on the right side of the hive was $16 \%$ (w/w), while the left flower remained at $33 \%$. The purpose of this control experiment was to check whether the experimental design allowed the assessment of behavioural discrimination. In the second experiment, the BBI experiment, we assessed the impact of BBI on foraging behaviour. In the control phase, the two flowers delivered a $33 \%(\mathrm{w} / \mathrm{w})$ sucrose solution. In the test phase, the solution of the flower on the right side of the hive was replaced by a sucrose solution $(33 \% \mathrm{w} / \mathrm{w})$ to which BBI at $100 \mu \mathrm{g} \cdot \mathrm{mL}^{-1}$ was added. Added protein in the feeding solution can increase its attractiveness to the bees (Pham-Delègue et al., 2000), so the control flower delivered a solution to which a neutral protein, $100 \mu \mathrm{g} \cdot \mathrm{mL}^{-1}$, BSA Bovine Serum Albumin was added.

\subsection{Statistical analysis}

For each bee, the interval durations between two foraging bouts were computed for visits in the same two hour daily observation. One feature of the interval data was the problem of the censored event. Indeed, for each bee, the interval between the last visit during the daily observation period and the next one was not recorded because the record ended before this event happened. Nevertheless it was possible to take into account the partial information contained in the censored data.

For each bee, we recorded the interval duration between successive visits. We analysed this return tendency by the mean of a Cox's proportional hazards model (Cox, 1972). This statistical approach is usual in the analysis of censored survival data (Collett, 1994; Dechaume Moncharmont et al., 2003) and it has been used by several authors for the analysis of ecological (Muenchow, 1986; Fox, 1993) or behavioural data (Haccou and Hemerik, 1985; Pons and de Turckheim, 1988; Haccou and Meelis, 1992; Wajnberg et al., 2000). Consider $t$ the time since the bee left the last flower visited. The model expresses the interval between two visits in terms of return tendency (so-called hazard rate). The return tendency $\lambda_{i}(t)$ is a probability that a worker bee $i$ returns to one of the two flowers at time $t$ given that she was not already on a flower. The $p$ possibly time-dependent 
covariates $z_{i}(t)$ act multiplicatively on the return tendency:

$$
\lambda_{i}(t)=\lambda_{0}(t) \exp \left[\sum_{j=1}^{p} \beta_{j} z_{i}(t)\right]
$$

in which $\lambda_{0}(t)$ is the baseline return tendency (socalled baseline hazard function), and $\beta_{\mathrm{j}}$ the regression coefficients that give the relative contributions of the covariates $z_{i}(t)$. The baseline return tendency function and the regression coefficients are estimated simultaneously by Efron partial likelihood maximisation (Kalbfleisch and Prentice, 1980). As explanatory covariates, we considered not only the types of flower successively visited but also the following nuisance variables. As a high number of foragers on the flower could induce competition, we considered the number of bees present on the flowers as a time dependent covariate. We also assessed the influence of the individual variability, the total number of visits and the number of the successive visits on the same flower already performed, before the current one, by the individual. We also checked the variability among days of observation as categorical covariates. We also analysed the duration of presence on a flower by the mean of a proportional hazards model. We included in the model multiple explanatory covariates: the quality of feeding solution, the variability among individual and among days of observation, and the number of bees present on the flower.

The aim of the modelling process was to determine which combination of potential explanatory variables had a significant effect. The significant effects of the several covariates were tested through an iterative procedure. We compared the adequacy of the several nested models (with the different combinations of covariates) using maximum likelihood tests. Two models were compared by their log-likelihood ratio that has an asymptotic $\chi^{2}$ distribution (Collett, 1994). The adequacy of the fitted model was assessed by making the martingale residual plots and checking for widely deviant data (see Dechaume Moncharmont et al., 2003, for an example of such plots). For all the models used, these diagnostic statistics did not lead us to suspect any over dispersion of the data. Moreover, to assess the proportional hazards assumption, we also examined the Schoenfeld residuals. These residuals were calculated using the Splus function coxz.ph (Venables and Ripley, 1999) for each covariate used in the models. As the smooth curves were flat and centred around zero, and as the statistical tests for significant slope in the scatter plots supported the interpretation of the graphical displays, we concluded that the proportionality assumption was reasonable for all the models.
The individual number of visits per hour on the flowers were analysed in a generalised linear model assuming a Poisson distribution. As explanatory covariates, we considered the treatment effect, the variability among individuals or among days. The analyses were done using Splus software (Venables and Ripley, 1999).

\section{RESULTS}

\subsection{Visits per hour}

During the control sucrose experiment, we recorded the foraging activity of 95 bees which performed a total of 2511 visits. For each flower we computed the mean number of visits per hour performed by the bees active on the flower (Fig. 1a). Both the quality of the feeding solution $\left(\chi^{2}(1)=75.74, P<10^{-5}\right)$ the variability among days $\left(\chi^{2}(8)=42.6, P<10^{-5}\right)$ and the variability among individuals $\left(\chi^{2}(94)=391\right.$, $P<10^{-5}$ ) significantly affected the number of visits per hour. There was no difference between flowers during the control phase $\left(\chi^{2}(1)=0.522, P=0.47\right)$, but when the feeding solution of the right source was replaced by a solution of sucrose $16 \%$, the activity increased on the richer flower and decreased on the poorer flower $\left(\chi^{2}(1)=63.6, P<10^{-5}\right)$.

During the BBI experiment, we recorded the foraging activity of 150 bees, which performed 7704 visits. The mean number of visits per hour is shown Figure 1b. Neither the variability among days $\left(\chi^{2}(8)=210, P<10^{-5}\right)$ nor the variability among individuals $\left(\chi^{2}(149)=391\right.$, $P<10^{-5}$ ) could be neglected in the assessment effect of the proteinase inhibitor on the number of visits per hour. There was no difference between flowers during the control phase $\left(\chi^{2}(1)=1.12, P=0.29\right)$. When BBI was added to the feeding solution of the right flower, the workers did not modify the number of visits on this flower $\left(\chi^{2}(1)=2.37, P=0.12\right)$, but the number of visits on the left flower (control BSA solution) was lower $\left(\chi^{2}(1)=6.17, P=0.012\right)$.

\subsection{Duration of presence on the sources}

During the control sucrose experiment, we recorded the foraging duration on the flower of 62 different bees, which performed a total of 351 visits to the feeders. The mean duration of 

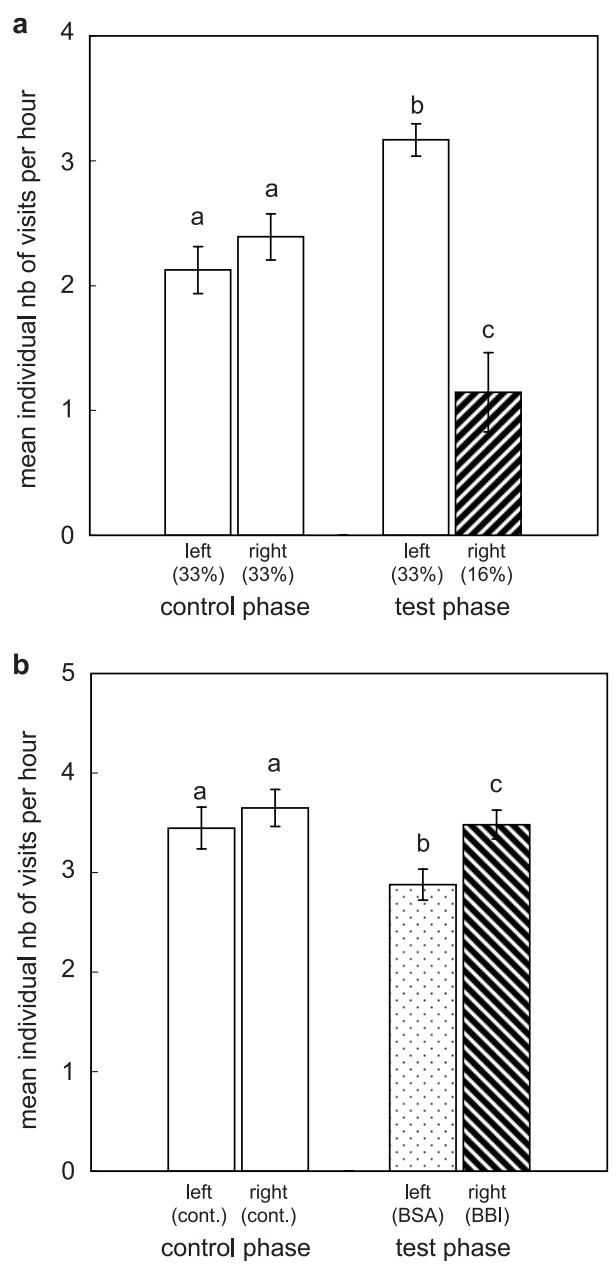

Figure 1. Mean ( \pm SEM) number of visits on the left and right flowers per hour in control and test phases. Different letters above bars indicate statistically significant effect of the flower on number of visits. [a] Control sucrose experiment: effect of the sucrose concentration, $33 \%$ (control) versus $16 \%$. [b] BBI experiment (cont. $=$ control $33 \%$ sucrose solution, $\mathrm{BSA}=33 \%$ sucrose solution to which the neutral protein BSA Bovine Serum Albumin $100 \mu \mathrm{g} \cdot \mathrm{mL}^{-1}$ was added, $\mathrm{BBI}=33 \%$ sucrose solution to which $\mathrm{BBI} 100 \mu \mathrm{g} \cdot \mathrm{mL}^{-1}$ was added).

presence on the feeder is shown Figure 2a. Neither the variability among days $\left(\chi^{2}(8)=31\right.$, $\left.P<10^{-5}\right)$ nor the variability among individuals $\left(\chi^{2}(61)=145, P<10^{-5}\right)$ could be neglected. The effect of the number of other bees on the feeder was not significant $\left(\chi^{2}(1)=0.29\right.$, $P=0.91)$. The durations of presence on the
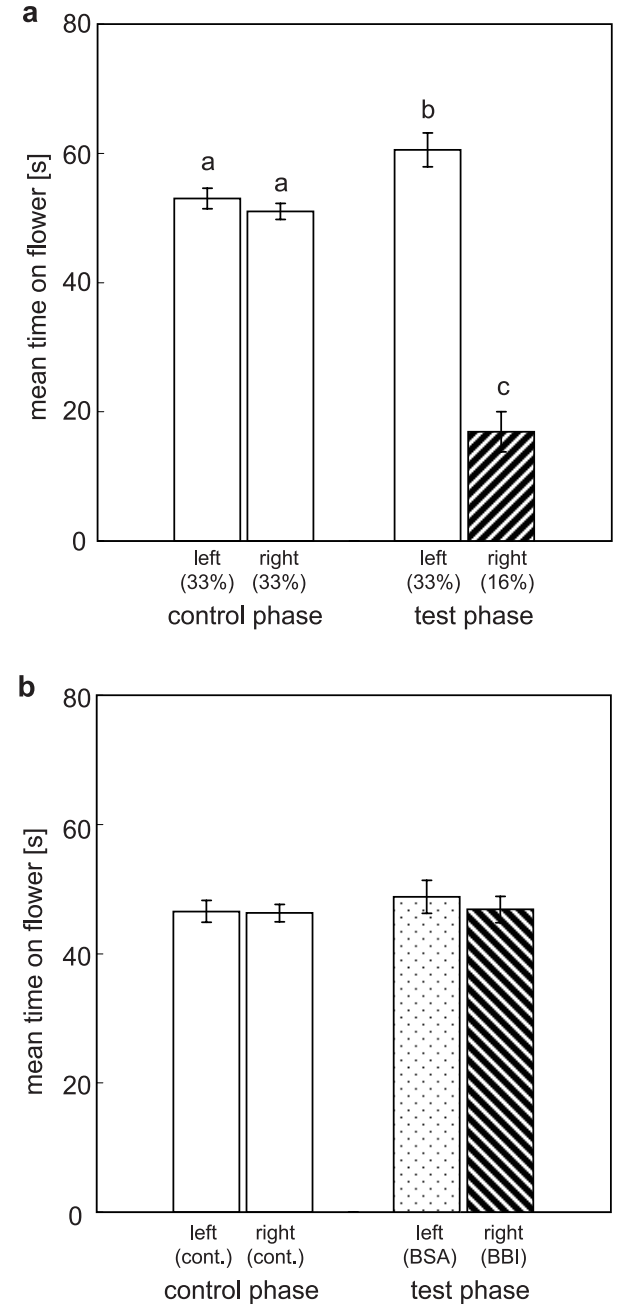

Figure 2. Mean $( \pm$ SEM $)$ duration time spent foraging on the feeder. Different letters above bars indicate a statistically significant effect of the flower on number of visits. [a] Control sucrose experiment: effect of the sucrose concentration (33\% versus $16 \%)$. [b] BBI experiment $($ cont. = control $33 \%$ sucrose solution, BSA $=33 \%$ sucrose solution to which the neutral protein BSA Bovine Serum Albumin $100 \mu \mathrm{g} \cdot \mathrm{mL}^{-1}$ was added, BBI $=33 \%$ sucrose solution to which BBI $100 \mu \mathrm{g} \cdot \mathrm{mL}^{-1}$ was added).

feeder were not statistically different between the two control feeders during the control phase $\left(\chi^{2}(1)=0.95, P=0.70\right)$. But when the feeding solution of the right source was replaced by a solution of sucrose $16 \%$, the activity increased 
on the richer flower and decreased on the poorer flower $\left(\chi^{2}(1)=43.1, P<10^{-5}\right)$.

During the BBI experiment, we recorded the foraging duration on the flower of 57 different bees, which performed a total of 350 visits to the feeder. Neither the variability among days $\left(\chi^{2}(8)=25, P=5.05 \times 10^{-4}\right)$ nor the variability among individuals $\left(\chi^{2}(56)=99, P=1.5 \times 10^{-4}\right)$ could be neglected. The effect of the number of other bees on the feeder was not significant $\left(\chi^{2}(1)=0.14, P=0.95\right)$. The quality of the feeding solution (Fig. 2b) had no significant effect on the duration of presence on the feeder $\left(\chi^{2}(3)=1.1, P=0.90\right)$.

\subsection{Interval duration}

For the control sucrose experiment, the number of shifts between flowers already done by the individual had no significant influence on the distribution of the interval duration $\left(\chi^{2}(1)=0.19, P=0.67\right)$. The effect of competition on the flower was not significant $\left(\chi^{2}(1)=0.57, P=0.45\right)$. Neither the number of successive visits on the source $\left(\chi^{2}(1)=1.47\right.$, $P=0.23)$, nor the total number of visits since the beginning of the experiment $\left(\chi^{2}(1)=1.75\right.$, $P=0.19)$ had significant effects. The following covariates had a statistically significant effect on the interval duration: the quality of the two flowers visited between which the interval was recorded $\left(\chi^{2}(3)=44.5, P<10^{-5}\right)$, the variability among bees $\left(\chi^{2}(86)=310, P<10^{-5}\right)$ and the variability among days of observation $\left(\chi^{2}(9)=222, P<10^{-5}\right)$. As can be seen in Figure $3 \mathrm{a}$, there was no significant modification of the interval duration when the bee leaves the good profitability flower $(33 \% \rightarrow 33 \%$ sequence $)$ to visit the lower profitability one $(33 \% \rightarrow 16 \%$ sequence) (Wald's test $\mathrm{z}=0.746, P=0.46$ ). But the return tendency on a poor quality flower $(16 \% \rightarrow 16 \%$ sequence) was significantly lower $\left(\mathrm{z}=5.17, P<10^{-5}\right)$ than on the good profitability flower $(33 \% \rightarrow 33 \%$ sequence $)$. Inversely, the bees leaving the low quality food source for the high quality flower $(16 \% \rightarrow 33 \%$ sequence) showed significantly higher return tendency $(\mathrm{z}=2.014, P=0.04)$ than during the control sequence $(33 \% \rightarrow 33 \%$ sequence).

For the BBI experiment, the number of shifts between flowers by the individual had no significant influence on the distribution of the interval duration $\left(\chi^{2}(1)=1.61, P=0.20\right)$. The
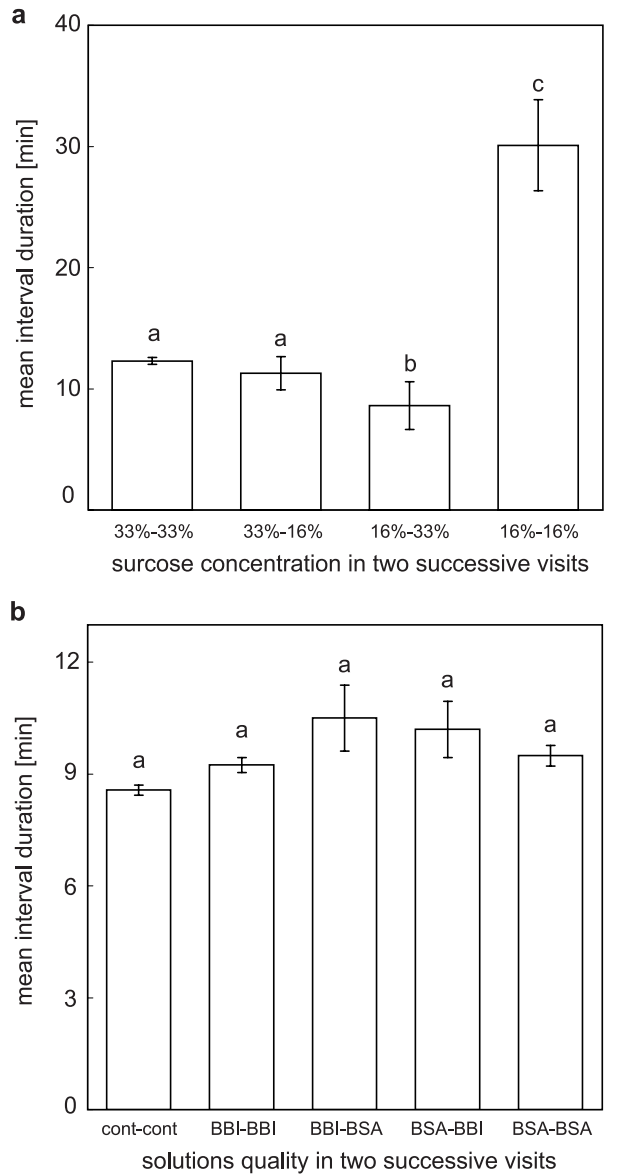

Figure 3. Mean $( \pm$ SEM) interval duration between two successive visits. The intervals were categorized according to the quality of the two successive solutions. Both mean and standard error to the mean were computed from the Kaplan-Meier estimator of the corresponding survivor functions. Different letters above bars indicate a statistically significant effect of the flowers quality on interval duration. [a] Control sucrose experiment: effect of the sucrose concentration. [b] BBI experiment: effect of the BBI proteinase inhibitor. The control solution is a 33\% sucrose solution.

effect of the competition on the flower was not significant $\left(\chi^{2}(1)=2.90, P=0.09\right)$. Neither the number of successive visits on the source $\left(\chi^{2}(1)=1.78, P=0.18\right)$, nor the total number of visits since the beginning of the experiment $\left(\chi^{2}(1)=3.38, P=0.07\right)$ had significant effect. As can be seen in Figure $3 \mathrm{~b}$, the quality of the two flowers visited had no significant effect on 
the interval duration $\left(\chi^{2}(3)=0.84, P=0.93\right)$. Only two covariates had significantly effect, the variability among days $\left(\chi^{2}(9)=135\right.$, $\left.P<10^{-5}\right)$ and the variability among individuals $\left(\chi^{2}(132)=763, P<10^{-5}\right)$.

\section{DISCUSSION}

The purpose of this study was to assess the impact of a proteinase inhibitor, BBI BowmanBirk Inhibitor, on the foraging behaviour of a pollinator Hymenoptera. At the dose of $100 \mu \mathrm{g} \cdot \mathrm{mL}^{-1}$ no statistically significant modification of the foraging strategy in the honeybee was observed.

\subsection{A colony scale study}

We assessed the impact of BBI at an intermediate scale: the colony level, over repeated observations of the foraging behaviour of free flying honeybees. We recorded continuously the behaviour of each individual over a 5 daycontrol phase and a 5 day-exposure to the inhibitor. Using a very large data set, based on a total of 7704 visits on the flowers performed by 150 bees, we were unable to detect any significant modification of the individual foraging activity when BBI was added to the feeding solution.

We first checked that the procedure was adequate to discriminate differential foraging behaviours. We showed the impact of the modification of the sucrose concentration in the feeding solution $(33 \%$ versus $16 \%)$ on the workers choice. Our results were in accord to those of Seeley et al. (1991), DeMarco and Farina (2001) and Pernal and Currie (2001) who demonstrated that bees accurately modify their behaviour optimise their foraging activity. But both concentrations chosen in our control sucrose experiment are highly valuable for the honeybees (Waller, 1972; Waddington and Kirchner, 1992).

The mean number of visits on the flowers is a global indicator of foraging activity. But it is not a sufficient parameter to assess a modification of individual foraging strategies. Thus, we focused on two other parameters: the distribution of the foraging duration on the source and the distribution of the durations between visits at the feeding place. During the control sucrose experiment, both distribution functions indi- cated that the worker bees modified their behaviour. The bees decreased their time spent on the source (and possibly the volume of solution carried to nest) when they foraged on the poor quality food source. The interval between two consecutive visits on the poor quality flower increased, while the interval before the return to the rich flower decreased significantly. Thus the procedure appeared to be reliable to assess modifications of the foraging behaviour.

\subsection{Impact of the BBI}

Previous studies of the impact of BBI on the honeybee had been already conducted at the individual level in laboratory experiments (Belzunces et al., 1994; Girard et al., 1998; Pham-Delègue et al., 2000). While BBI at $1 \mathrm{mg} \cdot \mathrm{mL}^{-1}$ significantly disrupted honeybees digestive physiology, survival and learning behaviour, BBI at $100 \mu \mathrm{g} \cdot \mathrm{mL}^{-1}$ did not increase mortality and did not disrupt digestive proteolytic activity or olfactory learning performances (Pham-Delègue et al., 2000). Thus we assessed the impact of a five day exposure to $\mathrm{BBI}$ at $100 \mu \mathrm{g} \cdot \mathrm{mL}^{-1}$ on the foraging strategy of free-flying foragers. The mean number of visits on the contaminated flower was not significantly modified by the presence of the inhibitor. The mean time spent on the feeder was not modified by the quality of the feeding solution. The interval duration between successive visits remained constant. We could not conclude that the bees did not detect the presence of BBI, but at least we concluded that honeybees did not significantly modify their foraging strategy when the proteinase inhibitor was added to the sucrose feeding solution.

Behavioural choice experiments have received little attention in studies examining the effect of transgenes on pollinator insects. Several studies based on no-choice assay, such as proboscis extension reflex, were previously carried out (Pham-Delègue et al., 2000) to check the learning performances after exposure to BBI. But these procedures were not designed to assess the free flying feeding behaviour. Possible avoidance (or attraction) by PI-contaminated food sources could occur in natural condition. This avoidance (or attraction) could only be checked in a behavioural choice experiment. The methodology proposed herein to 
test the feeding choice of free flying honeybees could form a colony scale risk assessment procedure. This procedure appears particularly relevant to the assessment of the impact of PIs or other transgenes to be possibly expressed in melliferous plants on honeybees and more generally to any pollinating insect.

\section{ACKNOWLEDGEMENTS}

We are thankful to Mercedes Chareton for rearing the bees and to Bernard Roger for technical assistance. F.X. Dechaume Moncharmont was supported by a Ph.D. grant from the National Institute for Agricultural Research (INRA), France. This study was carried out in the Laboratoire de Neurobiologie Comparée des Invertébrés, INRA, in Bures-sur-Yvette (France).

Résumé - L'inhibiteur de protéase de soja et la stratégie de butinage des abeilles domestiques en vol libre. En tant que pollinisateurs des cultures, les abeilles domestiques (Apis mellifera L.) sont susceptibles de butiner sur des plantes génétiquement modifiées résistantes aux insectes. Les inhibiteurs de protéase (IP) sont des produits de transgène de plus en plus utilisés dans le cadre de la lutte contre les ravageurs des cultures. Ils tuent ou limitent la croissance des insectes en perturbant la digestion des protéines. Il existe différentes classes d'IP dont l'efficacité dépend des protéases digestives présentes chez l'insecte. Or l'Abeille possède dans son tube digestif des protéases à sérine. Ainsi les abeilles qui butineraient sur des plantes transgéniques exprimant des inhibiteurs de protéase à sérine pourraient être affectées par ce produit de transgène. Des études précédentes au laboratoire au niveau individuel ont montré qu'une exposition à un inhibiteur de protéase, le Bowman-Birk Inhibitor (BBI) diminuait la physiologie digestive, les capacités l'apprentissage et la survie des abeilles. Cependant, en situation naturelle, les abeilles ont la possibilité d'éviter les sources de nourritures contaminées par des inhibiteurs de protéase. Or très peu de travaux ont porté sur les comportements de choix des pollinisateurs faces à des sources contaminées.

Nous avons évalué les stratégies de butinage d'environ une centaine d'abeilles en vol libre. Une expérience témoin, dans laquelle nous avons modifié la concentration en sucre du nectar, a vérifié que ce protocole permettait bien de discriminer des variations dans les stratégies de butinage (Fig. 1a, 2a, 3a). Nous nous sommes alors intéressés au comportement de 150 abeilles, issues d'une autre colonie, ayant effectué plus de 7700 visites sur deux fleurs artificielles dont l'une était contaminée par du BBI à $100 \mu \mathrm{g} \cdot \mathrm{mL}^{-1}$ (une concentration correspondant à la fourchette haute du niveau de production in planta). Nous avons évalué l'impact du BBI sur le nombre moyen de visites par heure sur chaque fleur (Fig. 1), sur la durée passée sur la fleur (Fig. 2), et sur les intervalles de temps entre les visites de chaque individu (Fig. 3). L'analyse statistique des données de durée a été réalisée au moyen de modèles de Cox. Au cours de cette étude, nous avons montré que le BBI à la concentration de $100 \mu \mathrm{g} \cdot \mathrm{mL}^{-1} \mathrm{n}$ 'affectait pas la stratégie de butinage des abeilles. De plus, le protocole d'analyse de l'évitement des ressources alimentaires par l'Abeille proposé ici pourrait constituer une méthode plus générale d'évaluation de abeilles à l'échelle de la colonie.

Apis mellifera / butinage / comportement de choix / inhibiteur de protéase / évaluation des risques / modèle de Cox

Zusammenfassung - Proteinaseblocker in Sojabohnen und die Sammelstrategie von freifliegenden Honigbienen. Als Bestäuber bei Feldfrüchten können Honigbienen wiederholt Insektengiften im Nektar transgener Pflanzen ausgesetzt sein. Zur Schädlingsbekämpfung werden immer häufiger Enzymblocker der Eiweißverdauung (Proteinase Inhibitor - PI) in transgene Produkte eingesetzt. Solche Blocker verlangsamen das Wachstum oder töten Insekten durch Unterbrechung der Eiweißverdauung. Es gibt mehrere Klassen von PIs und ihre Wirksamkeit hängt von den unterschiedlichen Enzymen zur Eiweißverdauung im Zielinsekt ab. Die Honigbienen haben Serinproteinasen in ihrem Verdauungstrakt. Honigbienen, die auf Pflanzen mit Blockern von Serinproteinasen sammeln, könnten diesem transgenen Produkt ausgesetzt und demnach geschädigt oder getötet werden. Frühere kleine Laborstudien ergaben eine Störung bei der Verdauung und beim Lernverhalten, nachdem sie dem Bowman-Birk Inhibitor (BBI) ausgesetzt waren. Unter natürlichen Bedingungen aber könnten die Honigbienen möglicherweise Futterquellen mit diesem PI meiden. Bei Untersuchungen über die Wirkung von transgenen Produkten auf bestäubende Insekten erhielten entsprechende Wahlversuche bisher wenig Beachtung.

Wir führten einen Wahlversuch mit frei fliegenden Bienen durch. Zunächst prüften wir bei Kontrollexperimenten die Eignung des Wahlversuchs zur Unterscheidung von verschiedenem Sammelverhalten (Abb. 1a, 2a, 3a). Danach protokollierten wir mehr als 7700 Besuche von mehr als 150 Bienen aus verschiedenen Völkern auf 2 Blüten. Während der Testphase war die Futterlösung auf einer der Blüten mit BBI $\left(100 \mu \mathrm{g} \cdot \mathrm{mL}^{-1}\right)$ versetzt, einer Dosis die etwa der Absonderungsmenge einer Pflanze entspricht. Zur Auswertung der Wirkung von BBI setzten wir die mittlere Anzahl von Besuchen pro Stunde (Abb. 1b), die mittlere Dauer des Aufenthalts auf dem Futter (Abb. 2b) und die Intervalle zwischen aufeinanderfolgenden Besuchen (Abb. 3b) fest. Zur 
Analyse wurde das Modell "Cox proportional hazard" genommen. Es ergab sich kein statistischer Unterschied zwischen Test und Kontrolle.

Apis mellifera / Sammelverhalten / Wahlverhalten / Proteinaseblocker / Risikoabschätzung / Cox-Modell

\section{REFERENCES}

Belzunces L.P., Lenfant C., Di Pasquale S., Colin M.E. (1994) In vivo and in vitro effects of wheat germ agglutinin and Bowman-Birk soybean trypsin inhibitor, two potential transgene products, on midgut esterase and protease activities from Apis mellifera, Comp. Biochem. Physiol. 109, 63-69.

Blight M.M., Le Metayer M., Pham-Delègue M.H., Pickett J.A., Marion-Poll F., Wadhams L.J. (1997) Identification of floral volatiles involved in recognition of oilseed rape flowers, Brassica napus by honeybees, Apis mellifera L., J. Chem. Ecol. 23, 1715-1727.

Burgess E.P.J., Malone L.A., Christeller J.T. (1996) Effects of two proteinase inhibitors on the digestive enzymes and survival of honey bees, J. Insect Physiol. 42, 823-828.

Christeller J.T., Burgess E.P.J., Mett V., Markwick P., Murray C., Malone L.A., Wright M.A., Philip B.A., Watt D., Gatehouse L.N., Lövei G.L., Shannon A.L., Phung M.M., Watson L.M., Laing W.A. (2002) The expression of a mammalian proteinase inhibitor, bovine spleen trypsin inhibitor in tobacco and its effects on Helicoverpa armigera larvae, Transgenic Res. 11, 161-173.

Collett D. (1994) Modelling survival data in medical research, Chapman \& Hall, London.

Cowgill S.E., Atkinson H.J. (2003) A sequential approach to risk assessment of transgenic plants expressing protease inhibitors: effects on non target herbivorous insects, Transgenic Res. 12, 439449.

Cox D.R. (1972) Regression models and life tables (with discussion), J. R. Stat. Soc. B 74, 187-220.

Dechaume Moncharmont F.X., Decourtye A., Hennequet C., Pons O., Pham- Delègue M.H. (2003) Statistical analysis of the Honeybee survival after chronic exposure to insecticides, Environ. Toxicol. Chem. 22, 3088-3094.

DeMarco R., Farina W. (2001) Changes in food source profitability affect the trophallactic and dance behavior of forager honeybees (Apis mellifera L.), Behav. Ecol. Sociobiol. 50, 441-449.

Dohmen G.P. (1998) Comparing pesticide effects on beneficial in a sequential testing scheme, in: McEwen P. (Ed.), Ecotoxicology: pesticides and beneficial organisms, Kluwer Academic Publishers, Dordrecht, pp. 92-109.
EPPO (1993) Decision-making scheme for the environmental risk assessment of plant protection products, Eur. Mediterranean Plant Protection Organization Bull. 23, 151-165.

Fox G. (1993) Failure-time analysis: emergence, flowering, survivorship, and other waiting times, in: Scheiner S.M., Gurevitch J. (Eds.), Design and analysis of ecological experiments, Chapman \& Hall, pp. 253-289.

von Frisch K. (1967) The dance language and orientation of bees, The Belknap Press of Harvard Univ. Press, Cambridge, Massachusetts.

Girard C., Picard-Nizou A.L., Grallien E., Zaccomer B., Jouanin L., Pham-Delègue M.H. (1998) Effects of proteinase inhibitor ingestion on survival, learning abilities and digestive proteinases of the honeybee, Transgenic Res. 7, 239-246.

Haccou P., Hemerik L. (1985) The influence of larval dispersal in the cinnabar moth (Tyria jacobaeae) on predation by the red wood ant (Formica polyctena): an analysis based on the proportional hazards model, J. Anim. Ecol. 54, 755-769.

Haccou P., Meelis E. (1992) Statistical analysis of behavioural data, an approach based on timestructured models, Oxford University Press, Oxford.

Hilder V.A., Gatehouse A., Sheerman S.E., Barker R.F., Boulter D. (1987) A novel mechanism of insect resistance engineered in tobacco, Nature 300, 160-163.

Hines M., Nielsen S., Shade R., Pomoeroy M. (1990) The effect of two proteinase inhibitors, E-64 and the Bowman-Birk inhibitors, on the developmental time and mortality of Acanthoscelides obtectus, Entomol. Exp. Appl. 57, 201-207.

Johnson R., Narvaez J., Ryan C.A. (1989) Expression of proteinase inhibitors I and II in transgenic tobacco plants: effects on natural defence against Manduca sexta larvae, Proc. Natl. Acad. Sci. USA 86, 9871-9875.

Jouanin L., Girard C., Binadé-Bottino M., Le Metayer M., Picard-Nizou A.L., Lerin J., Pham-Delègue M.H. (1998) Impact de colzas transgéniques exprimant des inhibiteurs de protéases sur coléoptères phytophages et sur abeilles, Cah. Agric. 7, 531-536.

Kalbfleisch J.D., Prentice R.L. (1980) The statistical analysis of failure time data, Wiley, New-York.

Kriston I. (1973) Die Bewertung von Duft- und Farbsignalen als Orientierungshilfen an der Futterquelle durch Apis mellifera L., J. Comp. Physiol. A 84, 77-94.

Masoud S.A., Johnson L.B., White F.F., Reeck G.R. (1993) Expression of a cysteine proteinase inhibitor (oryzacystin-I) in transgenic tobacco plants, Plant Mol. Biol. 21, 655-663. 
Moritz B., Crailsheim K. (1987) Physiology of protein digestion in the midgut of the honeybee (Apis mellifera L.), J. Insect Physiol. 33, 923-931.

Muenchow G. (1986) Ecological use of failure time analysis, Ecology 67, 246-250.

Odani S., Ikeneka T. (1977) Studies on soybean trypsin inhibitors: complete aminoaciods sequence of a soybean trypsin-chymotrypsin-elastase inhibitor, CII, J. Biochem. 82, 1523-1531.

Oppert B., Morgan T., Cubertson C., Kramer K. (1993) Dietary mixtures of cysteine and serine proteinase inhibitors exhibit synergistic toxicity toward the red flour beetle, Tribolium castaneum, Comp. Biochem. Physiol. 105, 379-385.

Pernal S., Currie R. (2001) The influence of pollen quality on foraging behavior in honeybees (Apis mellifera L.), Behav. Ecol. Sociobiol. 51, 53-68.

Pham-Delègue M.H., Girard C., Le Metayer M. Picard-Nizou A.L., Hennequet C., Pons O., Jouanin L. (2000) Long-term effects of soybean protease inhibitors on digestive enzymes, survival and learning abilities of honeybees, Entomol. Exp. Appl. 95, 21-29.

Pons O., de Turckheim E. (1988) Modèle de régression de Cox périodique et étude d'un comportement alimentaire, INRA Institut National de la Recherche Agronomique, Versailles, France.

Sandoz J.C., Laloi D., Odoux J.F., Pham-Delègue M.H. (2000) Olfactory information transfer in the Honeybee: compared efficiency of classical conditioning and early exposure, Anim. Behav. 59, 1025-1034.

Schuler T.H., Denholm I., Clark S.J., Poppy G.M. (2001) Population-scale laboratory studies of the effect of transgenic plants on non-target insects, Mol. Ecol. 10, 1845-1853.

Schuler T.H., Potting R.P.J., Denholm I., Clark S.J., Clark A.J., Stewart C.N., Poppy G.M. (2003) Tritrophic choice experiments with Bt plants, the diamondback moth Plutella xylostella and the parasitoid Cotesia plutellae, Transgenic Res. 12, 351361.

Seeley T.D., Camazine S., Sneyd J. (1991) Collective decision-making in honey bees: how colonies choose among nectar sources, Behav. Ecol. Sociobiol. 28, 277-290.

Venables W.N., Ripley B.D. (1999) Modern applied statistics with S-plus, Springer-Verlag, NewYork.

Waddington K.D., Kirchner W.H. (1992) Acoustical and behavioral correlates of profitability of food sources in honey bee round dances, Ethology 92, $1-6$.

Wajnberg E., Fauvergue X., Pons O. (2000) Patch leaving decision rules and the marginal value theorem: an experimental analysis and a simulation model, Behav. Ecol. 11, 577-586.

Waller G.D. (1972) Evaluating responses of honey bees to sugar solutions using an artificial-flower feeder, Ann. Entomol. Soc. Am. 65, 857-862.

Wenner A.M., Meade D.E., Friesen L.J. (1991) Recruitment, search behavior and flight range of the honey bees, Am. Zool. 31, 768-782.

Williams I. (1994) The dependence of crop production within the European Union on pollination by honey bees, Agric. Zool. Rev. 6, 229-257. 